\title{
The Cemetery, the State and the Exiles: A Study of Cementerio Colón, Havana, and Woodlawn Cemetery, Miami
}

\author{
Marivic Wyndham, University of Technology Sydney, and \\ Peter Read, University of Sydney
}

Cementerio Colón, Havana, is one of the great historical cemeteries of the world, and is generally held to be the second most important in Latin America-in historical and architectural terms - after La Recoleta in Buenos Aires. It was built in 1869 by the Galician architect Calixto Arellano de Loira y Cardoso, a graduate of Madrid's Royal Academy of Arts of San Fernando, and who became Colón's first occupant when he died before his work was completed. Yet for all its elegance and grandeur Cementerio Colón conceals as much as it displays. Empty tombs and desecrated family chapels disfigure the stately march of Cuban family memorials even in the most prominent of the avenues, and away from the central cross-streets, ruin. Many of these are the tombs of exiled families, whose problems with caring for their dead have been complicated by residence in new countries. In this article we consider both the earthly remains of the ancestors and how the Cuban-American diaspora of Miami tries to come to terms with what it is powerless to prevent.

The first impact of Cementerio Colón is a seemingly endless succession of tombs blinding white in the midday heat, few shade trees and nowhere to sit. In front of the main entrance, at the axes of the principal avenues Avenida Cristobal Colón, Obispo 
Espada and Obispo Fray Jacinto, stands the Central Chapel apparently modelled on Il Duomo in Florence. On every side rectangular streets lead geometrically to the cemetery's 56 hectares, designed by Loira to define the rank and social status of the dead with distinct areas, almost city suburbs: priests, soldiers, brotherhoods, the wealthy, the poor, infants, victims of epidemics, pagans and the condemned. The best preserved and grandest tombs stand on or near these central avenues and their axes.

Some two million Cubans have left the island by one means or another since 1959. Selfimposed exile began that same morning of 1 January at the dawn of the Revolution and has continued to the present. In the early years, those weighing the possibilities asked themselves - will it get any worse? Few imagined that they would not be allowed to return. The first organised mass-emigration scheme, Pedro Pan (1960-62), allowed 14,000 children to leave for Miami. The next significant wave was some 125,000 marielitos in 1980, after the Cuban government, following an economic downturn, announced that anyone who wanted to leave could do so. The most recent massemigration reached its peak in 1994 when the balseros (rafters), those despairing of a future in Cuba during the so-called 'Special Period,' left illegally during terrible economic and physical hardship following the collapse of Soviet aid to Cuba (Chávez 1999). In the last decade the chief constraint on emigration or escape is the disinclination of the USA to receive any more exiles or refugees, and the financial cost of leaving for Mexico or other Latin American countries. The small number of those allowed to leave will usually have to raise a huge 'exit tax'—perhaps $\$ 7,000$-imposed on them by the government (Ordóñez 1998). ${ }^{1}$

Whatever the motivations, the pain of leaving family and friends seems immediate and sharp. Other costs become apparent over months or years, and may include the awareness that Cuban-American society is by no means the paradise imagined by some who have never been there. Finally comes the realisation to most of the full cost: the departure was forever, the homeland is locked in fading memories, and links once severed can never be reforged (Pérez Firmat 1995; Arboleya 1996; Grenier \& Pérez 2003; Wyndham 2008).

Our paper concerns one of these latter-day, but nevertheless profound, costs in a culture

\footnotetext{
${ }^{1}$ See also the virtual exhibit, 'The Cuban Rafter Phenomenon: A Unique Sea Exodus' (2004).
} 
that continues to take seriously its ancestors and its respect for the dead. It deals with the exiles' inability to protect, from deterioration or vandals, the family tombs in Cuba, and their parallel inability to decide how to preserve the remains of those who have died in the new country. Our argument is largely drawn from reading the cemeteries as social artefacts.

There are not many models on how to read cemeteries in this way. The anthropologist Lloyd Warner (1959), the rabbi and author Rudolph Brasch (1987), the architect Howard Colvin (1991), and one of the authors of this paper, the historian Peter Read (2003), have gone some way to explore their social meaning, but the vast literature on cemeteries is largely (and astonishingly) apt to present cemeteries in terms of tombstones, genealogies and locations only. In the end, as is perhaps proper in matters of the spirit, social scientists must draw their models on exploring cemeteries from the poets. While Warner prosaically saw tombstones as 'the hard enduring signs which anchor each man's projections of his innermost fantasies private fears abut the certainty of his own death' (1959: 280), to Henry Handel Richardson, only Richard Mahoney's perishable body was absorbed by the 'rich and kindly earth of his adopted country,' for his 'vagrant, wayward spirit' remained elsewhere and peregrine (1954: 831). Federico Garcia Lorca was one of very many people of intuition who sensed the spirits of the buried dead nearby (Gibson 1989: 385-86).

\section{We begin the journey}

A stroll of fifty metres in any direction reveals the same pride and achievement in the city's and the nation's culture reflected in the official guide, not matched even by descriptions of the city Cathedral. The massive monument to the Fuerzas Armadas Revolucionarias (FAR, the Armed Revolutionary Forces) is a graceful marble open air pantheon containing the remains of national heroes guarded by two saluting bronze figures.

What the Cuban government wishes the visitor to absorb is contained in the handsome cemetery guidebook, The Guide to the Cristóbal Colón Necropolis in Havana (1999). The text begins:

Just a hundred metres from the most cosmopolitan area of Havana, 23rd street, and going up to 12th street to Zapata; amid the curious contrasting combination between frenzied movement and placid seclusion we come across the majestic entrance to the Cristóbal Colón (Christopher 


\section{Columbus) Necropolis.}

With a surface area of 56 acres it is considered to be the best monumental architectural cemetery in the world .... and it offers a domain of extraordinary magnificence and beauty which fascinates the visitor (1999: 2).

Now follows the general description, exuberant even by the standards of Cuban tourist literature: the cemetery is 'a domain of extraordinary magnificence and beauty which fascinates the visitor,' the Carrara marble is of 'virgin white richness,' the monuments are of 'incalculable' worth; note the 'magnificent Greek pavilions'; here the 'belligerence of the Medieval castle emulates with [sic] the robust strength of the pyramids' (2-3). While in cultural terms the Cuban state has no quarrel with its Spanish-Catholic heritage, such an enthusiastic response to the religious reliquaries are as striking as they are rare on the island. But beyond the imagery, the piety, the quaintness and the anecdote, the guidebook seeks to amplify the material remains of the national heroes of Cuba. Cementerio Colón is the nation's principal repository for its heroes of independence and revolution. It desires its visitors to be instructed in, and to celebrate, the disjunction between colonial/republican failures and revolutionary achievement. Like the permanent exhibitions of the Museum of the Revolution in Central Havana, the Colón guidebook follows a precise and didactic agenda.

Each of the guidebook's four suggested cemetery walking tours is designed to impress upon the visitor the inevitability of modern, especially revolutionary, history. The third itinerary, for instance, includes the tomb of Gerardo Abreu Fontán, the pro-Castro saboteur and insurrectionist who, in 1958, was 'captured and tortured with all the horrors and cruelties imaginable until he died in silence.' Next is a monument to young Spanish soldier conscripts, 'the true cannon fodder of the colonial wars of Spain,' mobilised by the Obligatory Military Service; then the Martyrs of the 13th of March 1957, who 'attacked the Presidential Palace in order to execute President Fulgencio Batista, the dictator who had flooded the country with blood' (The Guide 1999: 108-19). Elsewhere visitors are invited to inspect the monument to the republican hero Antonio Guiteras Holmes (actually buried in Matanzas province), whose death 'symbolised his bloody battles against the United States imperialist expansion in Cuba' (79), and the site at which people 'worship' at the tomb of the parents of José Martí, Cuba's foremost revolutionary hero of the wars of independence with Spain. The General Pantheon of the Veterans and Patriots commemorates the 'glorious deaths of the leaders in the battle for independence' (1). Nor is victory at the Bay of Pigs omitted from the national 
narration. Fe De Valle, who died in the incendiary attack on the famous department store El Encanto two days before the failed invasion, is awarded this ponderous eulogy by the guidebook:

[De Valle was] the first victim in Operation Pluto ... The military plan organized against Cuba under the name 'Operation Pluto' by the Central Intelligence Agency of the USA saw an air-sea invasion of the Bay of Cochinos, accompanied by a wave of sabotage and subversive internal actions during the days after the landing. This sabotage included setting fire to one of the largest department stories of the city. Fe de Valle, a humble worker, was carrying out the work round when this disaster struck. Not realizing the danger she was in she tried to recover the money which the syndicate had collected for the infant schools, but she did not have time to get out of the building before it came crashing down on top of her. (154)

Our perambulation so far has done nothing to suggest the sudden and permanent departure of the many thousands of sons and daughters whose task it was to care for the family tombs of their ancestors. Such evidence will not, however, be far to seek. Much more is to be found in the Colón cemetery than the state's depiction of its heroic or pietistic monuments. As much as mourning a buried presence, the cemetery is a memorial to absence. To find the evidence of the departure of more than two million Cuban citizens since the revolution one must put away the guidebook and explore a little further than the main thoroughfares.

Another street or two away, then, the cemetery begins to offer the historian, and the returning exile, more than national heroes. Colón's calculated resemblance to a real city, of central plaza, administration, grand avenues, humble streets and suburbs from very rich to very poor, speaks the life which in pre-revolutionary Havana existed both outside and inside the cemetery walls. In the Latin American Catholic tradition, the monument erected above the coffin was held to be as important as what the tomb contained. In the richer precincts, monuments to the dead once competed with each other in opulence, architectural daring or familial piety, or trumpeted the family achievement.

They do not compete in opulence any longer. We continue strolling down to this quiet corner in Calle 10, where a man has stepped from his 1956 Chevrolet to place a bunch of flowers on a well-kept grave. Clearly at least one of the descendants of this family has remained after fifty-one years of revolutionary government. Two streets away an exhumation is taking place, for a coffin has fulfilled its allotted two years in the ground and the space is needed for another burial next week. An extended family group of a hundred people are taking part in what is effectively a second funeral as the coffin 
emerges from the ground. In the next few days the bones will be placed in a cement box and stored with the hundreds of thousands of others that can be seen stacked in several more or less discreet parts of the cemetery. No one can be certain of identities, especially of those who no longer have protectors. After seeing a program depicting an exhumation in Cementerio Colón on television, Nedda G. de Anhalt wrote:

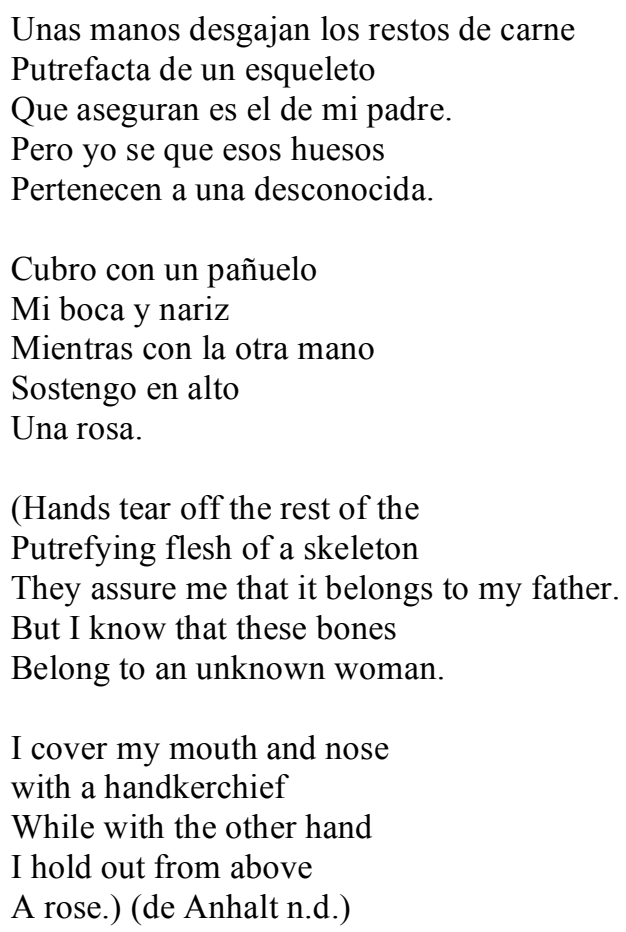

Here in Calle 14 a group of cemetery workers are unceremoniously disinterring half a dozen coffins of - who knows who they were? They seem to have no identification; surely they are the remains of those whose descendants departed, perhaps, decades ago. The men toss the coffins around as they lever off the more valuable lid from the unwanted pine box. The contents spill in ungainly heaps over the ground. The contents of the coffins, clothes, bones, loved objects, faded letters blow about in the wind or as the casual pedestrian steps over them, wait to be shovelled into the trailer. One cannot imagine such off-hand public treatment of the dead in La Recoleta, or the General or Municipal cemeteries of Santiago de Chile.

Such sights should not be altogether surprising in a nation at times desperately poor, without a crematorium, in an overcrowded cemetery with attitudes to death rather more frank and disclosed than in Anglo Saxon countries. Few Cubans have had the resources to spend on the preservation of family graves. The best that the mourners who remain can hope for is to keep the tomb swept and tidy, to change the flowers and to replace the 
funerary objects decaying with age. It is not surprising that the guidebook authors make nothing of the thousands of decidedly unkempt or deteriorated graves of the cemetery. To do so would be to draw attention to the families of the exiles, the gusanos - the worms - whom the state takes such pains to diminish. The Cuban nation will restore the abandoned or collapsing tombs of the heroes of the wars of liberation, but neither its finances nor its growing professional heritage consciousness will fill the empty tombs, replace the photographs, or do anything to restore the personal honour that once belonged to the families who began leaving their ancestors in 1959. Nor in Colón will it spend any money repairing the tombs of those judged to have been enemies of the revolution, whatever their status in republican times.

Consciousness of unfulfilled obligations and besmirched honour hang heavily on exile communities. To preserve those obligations was the reason why for many decades Cuban exiles in Miami drank a toast each Christmas Eve to 'Next year in Cuba.' Not to do so was to show that one had given up the hope of return, or as years went by, the pretence of the hope of return. Not to do so signified that they had forsaken the sacred trust to care for their inheritance, not least the tombs of their own parents and grandparents. Surreptitiously - to avoid accusations that any money spent in Cuba would serve to hold up the regime a little longer-some Cuban Americans began to send funds for tombs to be rewaxed to prevent the entry of moisture, or to repair the chapels and mausoleums, or to have the word Clausurada (closed) inscribed upon them. (Clausurada indicates that someone has paid a sufficient sum for the coffins inside to be left undisturbed.) Others, from abroad, paid the management or remaining family members to place flowers on the grave of their mother on Mother's Day, or her birthdate, date of death, or Christmas. To the cemetery explorer the sense is confirmed that the state guidebook will speak only for the tombs of those whose families remained in support of the revolution.

More revealing of whether or not a tomb has a local family protector is the condition of the shrine associated with the tombs of the once wealthy, the little chapels on the tombs, usually with windows and a glass or metal door. In these were placed, at the time of interment, perhaps a Madonna, devotional objects, a shelf holding several photographs, urns, flowers - and a broom. Some contain curtains, a chair or personal items of the deceased, so that the tomb of the dead becomes simultaneously a private living room 
sealed - it was hoped - for eternity. While a tomb well kept by local families may be in disrepair, the vases and photographs will still be dusted, rust and water stains scrubbed off. The family members will be too busy keeping their heads above the nation's perilous economic waters to spend money on further upkeep even if the materials for repair were available. But the chapels without a local protector, whose carers now live in the USA, Spain or Latin America, will soon be apparent.

Still disregarding the guidebook we continue our walking tour to the northwestern quadrant. Almost the first tomb we encounter has been stripped of everything movable. The remaining urns, once white and fixed to the floor, are stained with lichens or dust. A few paces away in the next tomb, a jagged triangular piece has been ripped from the floor of this chapel, which forms the roof of the tomb below. The door is locked, making it impossible to see what lies beneath. Pieces of the smashed segment lie about, and there is a lump of cardboard. At some point the space has been swept, to leave a neat but mysterious pile of grey and white stony rubbish on what remains of the roof of the tomb.

In this next grave, twenty metres further, the curtains once adorning the chapel-tomb have rotted and turned dark with age. The sagging holes and blackening fragments dropping onto the marble bench beneath lend the tomb an aspect more of macabre mutability than perpetual peace. A photograph on the shelf has inexplicably fallen on its face. Opposite, another tomb is entered by an exterior staircase that appears not to have been disturbed for forty years: one would need a machete to make an entrance. In the next avenue, the glass door of a chapel is smashed: only an iron grille prevents entry to the colourfully painted Madonna, who, standing on a plinth, almost touches the barrel vaulted roof. Still beautiful, she presides over a wheelbarrow, tools, cement bags, boxes and lumps of monumental masonry. Oddly she does not seem so out of place here amidst the detritus, as the Madonna in that empty violated tomb who now has nobody to protect.

The glass windows in a tomb nearby have evidently been broken and crudely replaced with hardboard. Cement falls off a corner to reveal the mundane brick beneath. An adjacent chapel has a smashed and broken door. One can enter to peer four metres to the bottom of the vault. All its former occupants have been removed. Why? Where to? When? Attitudes to the Catholic Church in Cuba, as in other socialist systems, have 
varied between ungracious tolerance to intense persecution; during the worst repressions churches that managed to remain open at all, might have to be entered through a back door; the faithful, always known to the local workers' collective, would have found promotion in their employment, and sometimes even to keep their job, difficult. At such times the devout used Colón tombs as a private or family shrine, and perhaps still do. But why remove the coffin if the space was not intended for another? Perhaps that topless, empty chamber was robbed first of its Carrara marble. Perhaps someone in downtown Havana is enjoying dinner on a very heavy white tabletop; more likely the slabs have been broken up for carving. The Cuban people have lived through some desperate times since 1959.

The sudden cut-off from the long dynasties expected and assumed by their members to flourish in Cuba forever, is never so clear as in the mausoleum of the family Núñez Gálvez. Gracelessly the guidebook describes the tomb as 'the result of tendencies which marked the guidelines of Cuban architecture during the mid-1950s an architecture which used daring designs in search of modernity'(61). What may be clumsy translation does scarce justice to this strikingly avant-garde, though now deteriorating, 1950s piece of architectural bravura. The guidebook photo depicts the elegant, soaring roofline but it does not reveal the interior façade where are listed, in barely half a column, the names of the six of the deceased family names. The procession of the dead halts abruptly six months before the revolution:

NÚÑEZ ÁLMAGUER
NÚÑEZ PÉREZ
QUINTERO CARRIÓN
NÚÑNZ PÉREZ
NÚÑEZ QUINTERO
NÚÑEZ BASULTO

NÚÑEZ ÁLMAGUER NÚÑEZ PÉREZ NÚÑEZ PÉREZ NÚÑEZ BASULTO
AGO 3 DE 1898
ABR 4 DE 1903
ENE 12 DE 1908
NOV 22 DE 1912
ENE 12 DE 1932
JUL 17 DE 1958

Evidently for the Núñez Gálvez family the revolution came suddenly and unexpectedly. Had the same slow rate of mortality continued, the columns would not have been filled for perhaps a thousand years.

The photographs of several other striking tombs are presented in the guidebook, but not referred to in the text. Presumably the authorities do not want attention drawn to them. One is that of the mother of Carlos Prío Socorrás, the last democratically elected President of the Cuban Republic. Another, strikingly modern tomb, and one of the most 
beautiful 1950s tombs in the cemetery, is the mausoleum of the journalists of the newspaper El País, the Reporters Association Pantheon. The above ground level section is a semi-elliptical glass, three metres deep. Glass panels form both sides of an entrance chamber, perhaps to represent the transparency of truth. The reinforcing beams allude dramatically to the shape of a cross. Although the architect has installed a little inspection window into the tomb at knee height on Calle J, it was possible in 2000 for visitors to enter through the smashed glass door to explore. The guidebook photograph is angled to hide it.

Below the entrance level area a staircase descends to two levels below ground. Barely half a dozen steps below the entrance the strong Havana sun weakens and filters into airy columns of dust, the atmosphere grows sinister and strange. The shadowy darkening staircase continues downwards to invite the curious and the strong minded. In the bottom chamber, two levels below the ground, lies perhaps what one should expect in a country that has endured more than one Special Period of starvation and neglect. Strange groups of letters are painted on the roof: KKK, and a word beginning NEOR. Lidless cement boxes of bones lie everywhere. About half the chambers reserved for the boxes along one wall are filled, the names of the deceased daubed crudely on the outside. A dozen boxes lie on their sides or upside down, their contents spilling onto the floor. At the bottom of the stairs to one several human bones lie scattered on a pile of the same tiny white and grey fragments we saw in the empty tomb on Calle F. These fragments are the decayed flesh of exhumed and destroyed bodies. One can imagine the course of events: a coffin in the empty tomb in the northwestern quadrant evidently was raised and emptied onto the floor of the chapel and the corpse ransacked, perhaps in the hope of extracting its gold teeth or jewellery. Probably workmen discovered the Calle F robbery and desecration a few days later. They perfunctorily swept the remains into a cement box, left the rest in a pile on the floor, and locked the grille.

Round the corner of this bottom chamber is a pile of another dozen boxes, their contents spilling over each in a pile of leg bones, clothes, hands, skulls, and other unrecognisable body pieces. Sprawled on top of this singular heap is what appears to be the blackened bottom half of a naked human form. Yet such apparent disrespect is arguably not the desecration of the dead, but reflects moments in the mundane life of a cemetery worker. Clearly the bottom level of the Tomb of the Reporters has been resumed by the 
cemetery employees as a work room, a preparation and disposal area more casual than disrespectful, where labourers reminiscent of Hamlet's sardonic gravedigger go about their diurnal business.

Ascend the stairs where the opaque filtering light reveals strange inscriptions, mysterious poems inscribed on the roof, walls and supporting pillars. We are in a huge, high chamber, one side of which holds the words and markings, the other a grid of burial chambers. A metre square, they resemble the spaces on the level below but bigger: here a full sized coffin was intended to be pushed and the entrance sealed. Some spaces are indeed still closed. The generous proportions and elegance of the chamber mark the interior as well as the glass ellipse as one of the most exquisite mausoleums in the land. Thus the first glance reveals what the tomb was meant to be. A second glance reveals what it now is. A third pinpoints the nightmare of all those charged with the care, across many continents and many centuries, of the revered and solemn dead-and must leave them behind.

Some of the spaces intended for coffins are empty. Several others retain a casket that has been broken into with a pick or a sledge hammer. Some coffins seem to be almost intact, the others only hold black and shattered remains. Pieces of desiccated human bodies, perhaps decades old, lie athwart the smashed boxes or lie on the floor. What looks like a rib cage is half inside a coffin, half out. Small and large pieces of bone and dark flesh are scattered in the shadows.

Written on the wall, mainly in what looks to be the same elegant hand, in black paint, are a number of verses. Some are inscribed four metres from the floor. All are weirdly poetic reflections on death and cemeteries. One reads:

\footnotetext{
Al fin de la vida pensamientos Hasta entonces no pensados Surgen claramente del espíritu Son como genios dichosos que se Posan deslumbrantes en la cima De lo passado.

(At the end of life thoughts Unimagined until now Rise clearly from the spirit They are like joyful beings which Throw dazzling light on the summit Of what has been.)
} 
Another reads, 'La vida no es solo un camino, sino una forma de vivir para aquellos que saben vivirla.' (Life is not only a track; rather it's a form of living for those who know how to live it). The most sinister of all, hard to read because it must have been written by someone balanced on the shoulders of another, declaims: 'Aquellos que son condenados a morir no deberían ser condenados por defender el derecho a vivir' (Those who are condemned to die should not be condemned for defending the right to live). Who could have inscribed such sentiments in such bizarre surroundings? Was the Tomb of the Reporters - is the Tomb of the Reporters - a chamber of torture as well as death? Were the Reporters selected for some after-death punishment, and by whom?

Several explanations are possible, but the source of the desecration is probably linked to Santería or other African-Cuban religions. Alonso cites a national sample of 5000 showing that 85 percent of Cubans in 2000 admitted a belief in, or reliance on, the supernatural, while only 16 percent belonged to an organised religion $(2010: 149,154)$. Before and after after the revolution Santería and similar African-derived religions remained defined as cults. The more esoteric rituals were often practised in secret. El Palo, for example, demands the ingestion of pieces of skull or finger tips whereby the living initiate becomes at one with the dead: no skulls or fingers are to be seen lying amidst the human remains scattered on cement floor ('Palo (religion)' 2009). Other cults, Protestant in origin, also conduct rituals out of sight among the cemetery tombs. A prominent Cuban anthropologist was eye-witness in 1995 to a nocturnal police raid on the Tomb of the Reporters in which a group of gay cultists were arrested for purported Satanic practices. It is possible that some of the wall inscriptions were written by members of this group (anon. pers. com., Jan 2004).

A Havana resident — his website name is 'Venus' — who visited Colón in 2000 was appalled at what he found when, by chance, he ran into what he called 'a mausoleum or something like it' of marble and glass, marked only with the letters $\mathrm{ABC}$ : their meaning was a mystery to him. Everything, he said on his website, was in a state of disarray:

si te asomabas a los cristales que servian de techo, podias ver todos los osarios en desorden, parecia, que en aquel lugar, lejos de encontrar reposo los difuntos, tenia el aspecto de haber sufrido una gran batalla. (if you looked through the glass ceiling, you could see that all the boxes had been disturbed; it seemed that in that place, far from finding rest, the dead had been through a great battle). (Venus 2000)

When he inquired of nearby workers as to 'the motives for such violence,' the answer 
he received was an urgent appeal for him to write of what he had seen and in so doing alert those with loved ones buried there. The website continued: 'Es necesario que lo hagan sin falta y si tienen familiares en ese mauseoleo, por llamarlo de algun modo, vengan a Cuba con urgencia a tratar de mejorar las condiciones de aquel lugar' (It is vital that you do this without fail, and for those with relatives in that mausoleum, that they come to Cuba urgently so as to improve the conditions of that place) (Venus 2000).

A second visitor to Colón despaired at what he called 'these acts of barbarism': 'la de tu difunto puede ser la próxima, nadie ve nada y parece que a nadie le interesa' (your dead relative could be next, and no one sees anything and it seems no one cares). And yet, to what public authorities could he denounce such things?:

\begin{abstract}
en el Cementerio Colón, parece que los encargados de su conservación, no tienen ni ojos ni voz, pues los que descansan ya no parecen ser tenidos en cuenta y los que alli vigilan, solo tienen ojos para cuidar aquel lugar por el cual reciben algún dinero. (at Colón Cemetery, it seems that those in charge of its conservation have neither eyes nor voice, as those who rest there are not taken into account, and those who watch over them only have eyes to care for that place for which they receive some money)
\end{abstract}

las verdaderas fotos de Cuba, serían las que se publiquen una vez que cualquiera de las personas que visite ese lugar, con una camára en mano y sin ser profesional ponga a la vista de todos, lo que escasamente pueda alguien describir con sus palabras (the true photographs of Cuba will be those published once anyone - it does not have to be a professional — who visits this place, with a camera in hand lays bare for all to see what can scarcely be described with words). (de Flores 2000)

Not surprisingly, the degenerated state of the Colón Cemetery is by no means unknown to Cuban-Americans. One wrote, after visiting the cemetery: 'Al parecer serán tomadas medidas inmediatas de vigilancia con un cuerpo de serenos para que los disfuntos puedan descansar en paz ... y sus familiares también' (It appears that they will take immediate measures to establish cemetery viligantes so that the dead can rest in peace $\ldots$ and also their families.) (de la cova n.d.)

Another Cuban American website on Cementerio Colón concludes with the observation that 'El Cementerio Colón es un testigo mudo del deterioro de nuestro país después de la revolución de la desgracia del comunismo' (The Colón Cemetery is a mute testimony to the deterioration of our country since the revolution of the disgrace of communism) (Vizcaíno n.d.). The same website asserted that a robbed skull will cost between US\$20 and $\$ 30$. It alleged that a grandmother saw a child wearing the burial clothing of her granddaughter three days after her funeral. The webpage author, María Argelia Vizcaíno, writes: 
I don't wish to alarm my compatriots in exile who have left their family dead behind, but to denounce the horrible fact ... It is a sorrow that one of the most famous and beautiful cemeteries in our continent, the totalitarian system who holds power in Cuba has brought to these extremes. May God take pity on the souls of our dead because their bones have not been able to rest in peace. (Vizcaíno n.d.)

But to limn the gathered darknesses of the Tomb of the Reporters is not necessarily to make a political judgement on the Cuban state. There is no indication that the government wishes the cemetery to be in such a state; indeed the advance of AfroCuban mortuary practices is decidedly unwelcome to the regime. Nor is it surprising that an official text on El Palo says nothing about its links with death rituals (Barnet 1995). However, its priorities to first restore the Spanish colonial architecture is obvious throughout the city.

\section{The cemetery of the exiles}

Yet Cuban-Americans do not come to the desecration of Colón with their own histories untroubled by trauma and doubt. Exiles living in Miami for much of their lives have been haunted by the memories of their unfulfilled deep filial obligations, and as they aged some became preoccupied with the dichotomy between their own future American resting places and those of their ancestors resting in Cuba:

\footnotetext{
In the case of my own family, when the unthinkable happened, and my parents' ageing generation of Cuban American exiles found themselves marooned indefinitely on foreign shores, the spectre of death in someone else's land seemed the cruellest blow of their long years of exile. They were not the first Cuban exiles to die so near, yet so far from their beloved island. Exile has a long history in Cuba. But they were our parents. These were our dead and something perverse seemed to overtake the natural order of things. (Wyndham 2008: 268)
}

Probably the majority of Cuban exiles who have died in Miami are buried in Woodlawn Park Cemetery, Dade County. The contrasts with Havana are striking. Where Cementerio Colón is grossly overcrowded, with scarcely a tree or bench to succour the weary mourner, Woodlawn is green and spacious. While Colón families may expect their older family graves, at least, to be grouped together, Woodlawn families may have to walk half a kilometre from one grave to the next, and frequently cannot remember the location of all the tombs they wish to visit. There are more visitors in Colón, but fewer cars. There are many more architectural marvels, family plots, beautiful ornate chapels, eloquent statements of public service and effigies of La Virgen de la Caridad del Cobre, the Patron Saint of Cuba, but no Cuban flags. In Woodlawn the visitor will find more seats, lawns, trees, spaces, but fewer, far fewer, religious sculptures. A few tombs stand out - of the Bacardí family, for example, or of Jorge Mas Canosa, the founding 
president of the Cuban-American National Foundation. The family names of the deceased are abbreviated down to two or three rather than, in the Spanish style, perhaps as many as a half a dozen, in answer to an unspoken, 'Well that will do for now, until we get back to Cuba.'

To construct an elaborate tomb after 1959 was to signal to the world that this family did not expect to return to the island soon. A lavish display would clearly imply that the future of Cuban exiles was permanent United States residence and citizenship. Many of those who first fled from Castro's revolution had already spent periods of exile in Mexico, or in the Dominican Republic or the USA. Often women and children did not bother to leave as the men endured - or enjoyed - a year or two away from domestic or workplace responsibility. From 1959 the exiles left Castro's Cuba in the same expectation that they would triumphantly return within a year or two. The unspoken message of the dead was: 'We do not wish to lie here permanently. Do not enshrine us here.' The failure of the Bay of Pigs invasion in 1961 was the first intimation that they might remain in exile in the long term, their lost places forlorn, their culture truncated, the graves of their ancestors uncared for. While the family of Núñez Gálvez expected to be inscribing the names of the family dead on their modernist tomb for hundreds of years in Colón, the Woodlawn dead were not expected to remain buried there even for the lifetime of their own children. Some did not want even the impermanence of Woodlawn. It is said that sprinkling the cremated ashes of exiles into the Florida Straits between Miami and Cuba is by no means unknown among the ageing first generation of exiles. Such a practice is disdained in Cuba itself, where contiguity with one's family dead is still held firm.

Some explanations for the differences are obvious. Miami's Cuban lifestyle is cars, money, multiple jobs, distance, ambition, declining religious rituals, rush. Many second-generation Cuban-Americans would find it unreasonable to be asked to drive a parent or aunt to Woodlawn to visit a grandmother, and they are not asked to do so. As in many other areas of the USA, the ceremonies of death have become less ritualised, less overtly religious, more commercialised. While, as in Havana, most CubanAmerican families will hire a funeral home for the wake over two or three days between the death and the burial, the cemetery service itself is usually short. There may be a police escort of the hearse requested, and paid for, in the will. It may be secular, just a 
single eulogy, immediately after which almost all the mourners will retire as if insulating themselves from the more confronting ancient rituals of lowering the coffin and casting earth upon it. After the ceremony, Woodlawn custom is to mark the burial site only by a bronze plaque and a removable metal flower holder. During a large burial service, people may stand, unknowing, on a grave covered by a mat for the duration of the service.

Woodlawn has inevitably claimed its own permanence in the lives and deaths of generations of Cuban exiles.

\begin{abstract}
In the case of my family, an earlier political exile in the early 1950s had taken us to Miami. There my paternal grandmother died and was buried. This was to be her temporary resting place, awaiting the time when things in Cuba 'improved' and we could transport her remains to their rightful place at the family plot at Cementerio Colón. It was never a question of 'if' but of 'when.' As it happened, we returned to Cuba until the revolution - and she stayed in Woodlawn. Before long, another period of exile had overtaken our plans to re-settle in Cuba and, in 1959, we found ourselves once again living 'temporarily' in Florida. where pilgrimages to her grave-in-exile became a regular part of family life. It was only with the death of my father in the early 1990s that we realised that my grandmother's temporary grave had now become her final resting place: my father's grave in the same cemetery ironically conferring permanence on hers. (Wyndham 2008: 275)
\end{abstract}

If the Colón guidebook carries a photograph of (but makes no comment upon) the tomb of the mother of Prío Socorrás, in Woodlawn stands the much more eloquent tomb of her more famous son. Beneath a tiled Cuban flag on the Woodlawn cement monument is inscribed, 'CARLOS PRÍO SOCORRÁS 1903-1977,' followed by ten lines of homily. ${ }^{2}$ Could a guidebook explain why a Cuban flag was thought to be necessary on his tomb, but not that of his mother?

Nowhere are the troubled and complex emotions of Cuban exiles more apparent than in the configuration and the wording of the collective memorials. The grave of the Unknown Soldier reads:

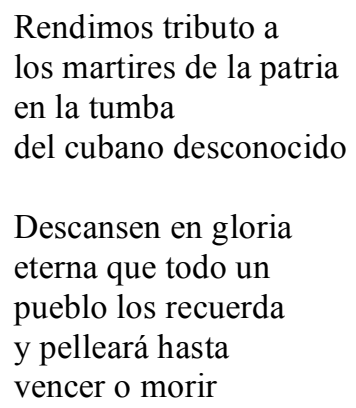

\footnotetext{
${ }^{2}$ See the photograph of the tomb on the Prío Socorrás page on wikipedia ('Carlos Prío Socorrás' 2010).
} 
(We pay tribute to

the martyrs of the patria

in the tomb

of the unknown soldier.

Rest in eternal

glory that a whole nation

may remember them and

fight until victory or death)

The call to arms evidently was not considered necessary for non-speakers of Spanish for the bronze plaque in English at the other end of the tomb is factual rather than pleading:

\author{
Here rests in glory \\ a Cuban freedom fighter \\ known only to God
}

The main Cuban Woodlawn memorial to the Unknown Soldier is a huge slab of black marble on which is etched, in white, an outline of the island. Its remarkable inscription reads:

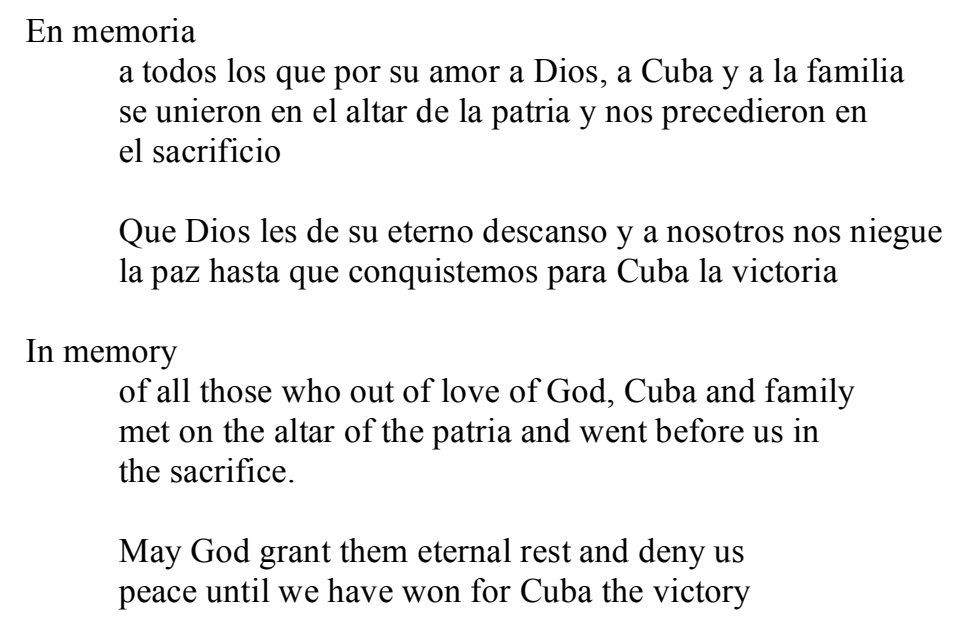

The shame that ought to be felt by those who did not so sacrifice themselves is almost palpable. The area is enclosed to form a square bounded by hedges and flanked at the formal entrance by the Cuban and US flags-legally necessary, but also serving to remind the Americans that Cuba must also be reclaimed by the efforts of the USA.

Despite the initial impermanence of Woodlawn, probably no former Havanan is planning to repatriate the remains of their ancestors to Cementerio Colón at the moment when the Cuban communist regime falls. How long a period of political stability would be necessary to ensure that a returning exile might not be forced abroad again? Nobody knows. Nor, indeed, are the ageing generations of exiles planning to have their own 
remains repatriated to the land of their birth. They wish to be honoured by their grandchildren, who, born in the USA, have made it obvious enough that they intend to remain citizens of the United States, not the new Cuba. If the tie to the patria remains for older people firm, the link with ancestors has been broken. Cuban-Americans seem to prefer to have their remains placed close to family members who died since 1959siblings and parents - rather than amongst more ancient descendants whose remains by now could have been destroyed. Most young Cuban-Americans have no desire to be sacrificed to any overseas cause; their victory will be to prosper in the land in which they were born and to which they now believe they owe their first allegiance. Indeed, the strong oppositional nature of Cuban exile may well diminish rapidly for all the exiles without its nemesis, the Castro brothers (Grenier \& Pérez: 120). The chasm between the two cemeteries, the two peoples, the widening generations, may never now be bridged.

\section{Acknowledements}

We acknowledge the helpful response of two anonymous referees to the first draft of this article. Portions of this article are adapted from Peter Read, 'And the Dead Remain Buried,' Humanities Research, vol. 10, no. 3 (2003): 47-55.

\section{Reference List}

Aruca, N. G. Menocal, L. \& Shaw, E. 1996, 'The Cristóbal Colón Cemetery in Havana,' The Journal of Decorative and Propaganda Arts, vol. 22, Cuba Theme Issue, 37-56.

Arboleya, J. 1996, The US-Cuba Migration Conflict. Melbourne: Ocean Press.

Arenas, R. 1995, Antes que anochezca. Barcelona: Tusquets Editores.

Barnet, M. 1995, Cultos africanos: La regla de Ocha. La regla del Palo Monte. La Habana: Artex.

Brasch, R. 1987, Permanent Addresses. Sydney, Collins.

'Carlos Prío Socarrás' 2010, Wikipedia. Online, available: http://www.wikipedia.org/wiki/Carlos_Prio_Socarras [Accessed 1 July 2010].

Chávez, E. R. 1999, 'The Migratory Crisis of the Summer of 1994,' Cuban Migration Today. Havana: José Martí.

Colvin, H. 1991, Architecture and the After-Life. New Haven, CN: Yale University Press.

'The Cuban Rafter Phenomenon: A Unique Sea Exodus' 2004, University of Miami Digital Library Program. Online, available: http://balseros.miami.edu [Accessed 2 Dec. 2010].

de Anhalt, N. G. n.d, 'Ritmos,' Elate.com. Online, available: http://www.elateje.com/0307/ poesia030701.htm [Accessed 1 July 2010].

de Flores, D. 2000, 'Cementerio.' Realidad Cubana, Conexion Cubana. Online, available: http://www.conexioncubana.net/realidad/urbanismo/cementerio.htm [accessed 1 Feb. 2010].

De la Cova, A. n.d., 'Santería, huesos.' Rose-Hulman College. Online, available: http://www.rosehulman.edu/delacova/religion/santeria-huesos.htm [accessed 12 July 2003].

García, M. C. 1996, Havana USA: Cuban Exiles and Cuban Americans in South Florida. 1959-1994. Berkeley: University of California Press.

Grenier, G. J., \& Perez, L. 2003, The Legacy of Exile: Cubans in the United States. Boston: Allyn and Bacon. 
The Guide to the Cristobal Colón Necropolis in Havana 1999, La Habana: Com-Relieve SA, Fid-Escudo De Oras, SA EEC.

Ordóñez, C. G. 1998, Como éramos y por qué nos fuimos. Miami: Original Impressions.

'Palo (religion)' 2009, Wikipedia. Online, available: http://en.wikipedia.org/wiki/Palo_(religion) [Accessed 2 Dec. 2010].

Pérez Firmat, G. 1994, Vida cultural cubanoamericana. Madrid: Colibri. 1995, Next Year in Cuba: A Cubano's Coming-of-Age in America. New York: Doubleday.

Read, P. 2003, Haunted Earth. Kensington: University of New South Wales Press.

Richardson, H. H. 1954, The Fortunes of Richard Mahoney. Melbourne: Reprint Society.

Venus 2000, 'Una visita al cementerio.' Realidad Cubana, Conexion Cubana. Online, available: http://www.conexioncubana.net/realidad/urbanismo/ cementerio.htm [accessed 1 Feb. 2003).

Vizcaíno, M. A. n.d., 'El cementerio de Colón.' Cubanmotives.com. Online, available: http://www.cubanmotives.com.Espanol/Articulos/Maria_Vizcaino/elcementerio_de_colón [Accessed 1 Feb. 2003].

Warner, L. 1959, The Living and the Dead. New Haven, CN: Yale University Press.

Wyndham, M. 2008, 'Dying in the New Country,' in P. Allatson \& J. McCormack (eds), Exile Cultures, Misplaced Identities. Amsterdam \& New York: Rodopi, 267-76. 